\title{
The Implementation and Experience of Integrity Management in Public Administration
}

\author{
Eszter DARGAY ${ }^{1}$
}

I know, there is no perfection on earth. To accept imperfection - in a certain sense, can bring us towards perfection - in spite of everything. It is the most to reach the maximum.

János Pilinszky²

To achieve integrity requires continuous attention, it is not a coincidence that integrity in Hungarian is often used together in one phrase with "development". If integrity is regarded identical with the perfection in the quotation above, it gets even more manifested that its realization or at least approaching it-needs continuous actions and studies.

The study presents the appearance of integrity concept and the experience of the integrity management's implementation in Hungary.

Keywords: public administration, integrity management, corruption-prevention, public administration development

\section{Introduction}

In Hungary, it was in connection with anti-corruption policy that the integrity approach entered public consciousness. However, several circumstances have made us look beyond this initial viewpoint and consider integrity concept as a phenomenon necessarily pervading the whole public administration system.

In order to show this change, I would like to show the experiences of integrity management in Hungary since it was introduced in 2013. The complex approach requires the analysis of the legislation and its practice at home in the light of international results and trends.

Ph.D. student, National University of Public Service; e-mail: dargay.e@hotmail.com; ORCID: 0000-00018404-2459

2 The quotation is from an interview given by János Pilinszky in 1974. 


\section{International Outlook: Anti-Corruption, Integrity Trends and Approaches}

The changes in international relations in the last decade of the $20^{\text {th }}$ century as well as the anti-corruption fight coming into view have brought important results.

On the one hand, these results appeared in international conventions to which Hungary joined. ${ }^{3}$ Though in the documents of certain international organisations (OECD, UN, EU, EC) the concept of corruption is partly differently interpreted, there is a common element: they all highlight its devastating impact on economy, business life and public service. The conventions do not consider corruption exclusively a criminal law issue, but-in this period-a privileged role is attributed to criminal law in the anti-corruption fight. [1]

Besides hard control, "soft" control is gradually gaining space in the international arena, too: manifested in guidelines, proposals and declarations.

Investigating anti-corruption policy, we must pay attention to the public administration trends. The New Public Management-adapting to the task sharing expectations of the neoliberal economy policy-focuses on the requirements of economy, effectiveness and efficiency. As an almost necessary consequence, a Good Governance model was born. Sensing the dysfunctional operation of this policy, since the millennium, the focus have shifted to value-orientation.

The framework of public service integrity interpretation is given by the society-this wide context was already mentioned in an essay carried out by the Irish-Dutch EU presidency collaboration in 2004. [2] The key statement of the study is: incorruptible behaviour in the public sector does not depend on one single instrument such as effective disciplinary legislation, the setting-up of efficient control and monitoring bodies or an attractive code of conduct, but on the existence of an overall national integrity system, a multi-pronged anticorruption strategy, or a multi-dimensional ethics infrastructure. The main characteristic of such a multi-dimensional approach is that ethics is considered a key principle of good governance.

The main motivation of the Ethics Framework [3] published under the auspices of the European Public Administration Network in 2004: one of the major policy themes of the governments of the EU member states focuses on increased attention to society's shared standards and values. The document points to the fact that corruption is especially harmful to integrity as it has a great impact on its authority and, consequently, on the effectiveness of the administrations' actions. On the other hand, integrity encompasses much more than the absence of fraud and corruption.

The Integrity Framework of the OECD was published in 2008. [4] It points out that the public sector integrity management has been high on the agenda in many OECD countries. Underlying this evolution is a growing understanding that integrity is a keystone of good governance, a condition for all other activities of government not only to be legitimate and trusted, but also to be effective. Indeed, the pioneering work of, among others, the

See the OECD Convention on Combating Bribery of Foreign Public Officials in International Business Transactions (1997), the Council of Europe Criminal Law Convention on Corruption and the Civil Law Convention on Corruption (1999), the European Union Convention on Fighting Corruption Involving Officials of the EU or Officials of Member States (1997), the United Nations Convention against Corruption (2003). 
OECD shows that investing staff and financial resources in integrity may also increase the effectiveness of government policies.

The paper provides a comprehensive approach to review and modernise instruments, procedures and actors for fostering integrity and preventing corruption.

The authors of the OECD Framework state that the integrity management of an institute is the collection of instruments, processes and structures. In the public sector, integrity management system can be built systematically, in a comprehensive manner on three pillars. The operation system itself is dynamic and basically self-developing and selfperfecting in which the good practices worked out in different countries play an important role. The OECD Framework classifies the possible instruments of the four main functions as following:

- determining and defining integrity within the organisation;

- continuous guiding in favour of integrity;

- monitoring integrity;

- enforcing integrity. [5]

As described above, the attention has been drawn to integrity as the tool of corruption prevention. However, the international trends have gone further soon: integrity development is defined as the basis of value-oriented, effective operation.

The corruption prevention function is well outlined; the integrity brought to the fore is considered the supplementary of repressive, basically criminal law tools. It is obvious that it has become ordinary to classify corruption prevention policy by how they bear the features of the two main tool-arsenals.

Báger distinguishes: [6]

- countries applying both repression and prevention-Singapore, Lithuania and Poland;

- countries bringing repression to the fore-the United Kingdom, Hungary in 2012;

- countries preferring integrity based prevention-Holland, Belgium and Slovenia.

\section{The Concept of Integrity and the Essential Elements of Integrity Approach}

According to the Cambridge Dictionary, ${ }^{4}$ integrity means the quality of being honest and having strong moral principles that you refuse to change. The concept refers to a status: a person acts according to legal and ethical requirements. Honesty includes the harmony of actions and thoughts meaning that the law abiding and morally correct activity comes from within. Finally, the concept also includes an active element: moral conviction makes you resist contrary, inappropriate actions and temptations. Applying this concept for public sector, all these must be interpreted beyond the individual level; at organisational level. Integrity in public administration means a mode of operation that enables public service and public sector bodies to effectively use their power and resources in order to accomplish officially accepted and certified public interest. [7]

4 See source: https://dictionary.cambridge.org/dictionary/english/integrity 
Summing up: the main theses of the application of integrity approach in public administration are the following.

On the one hand, the integrity approach in public service is a basic criterion; so that public service could fulfil its mission and work for the public interest and common wellbeing. On the other hand, integrity is an instrument at the same time; armouring public administration to be resistant to violations of law and risks that may endanger its operation. And finally, corruption basically fights against the principles above; it is the main threat to integrity; however, the mere absence of corruption does not mean integrity.

What we mean by integrity system may be distinct in different countries. The EU offers a possible toolbox in the publication published in 2015 Quality of Public Administration. A Toolbox for Practitioners. The document searches for appropriate solution suggestions to embed ethics and fight against corruption. [8]

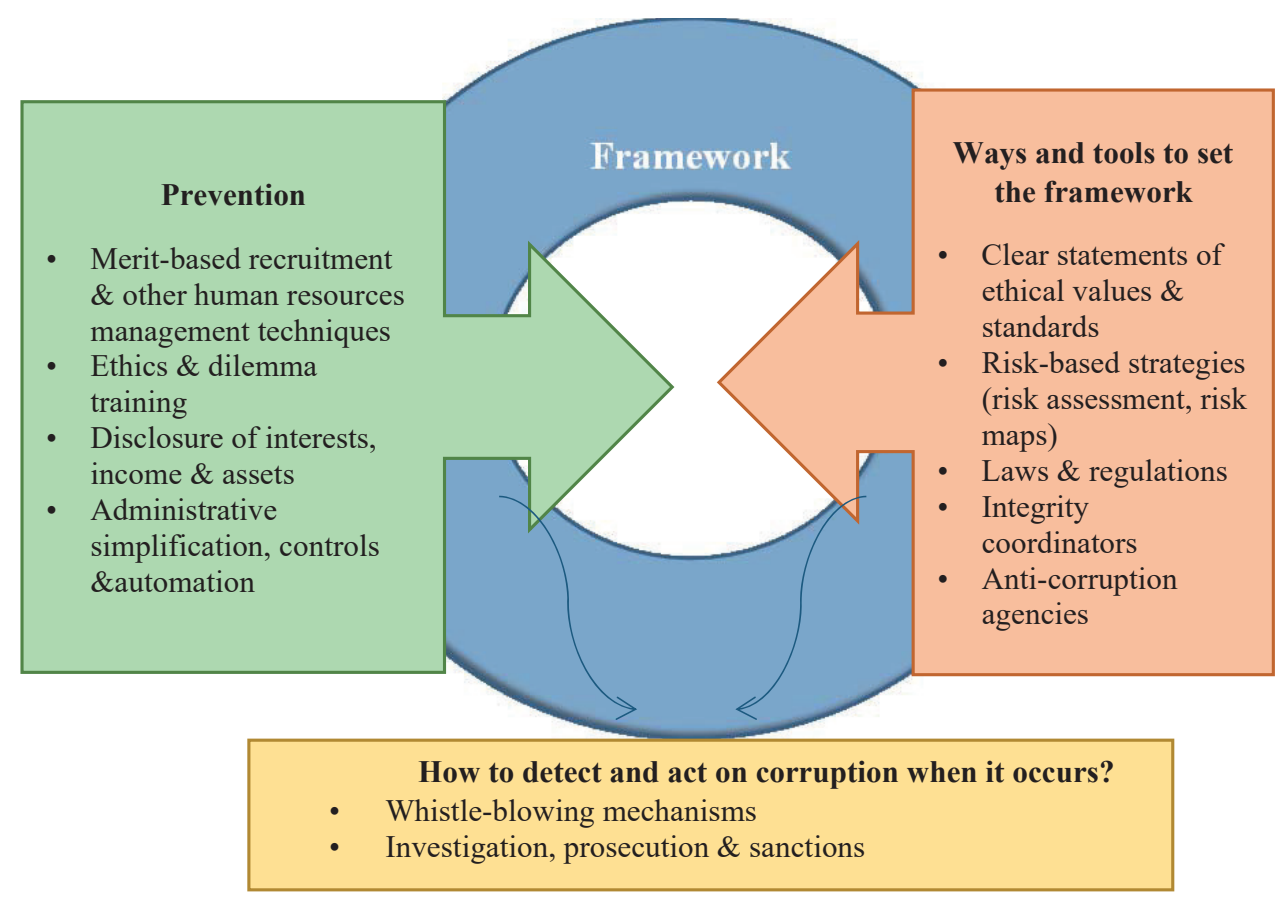

Figure 1. The framework of integrity management.

(Edited by the author based on [8].)

The contents of the document can be briefly summed up in the graph above. The basis of the framework is the method of prevention itself; it can be achieved by different tools, from various directions. A great majority of these tools does not exclusively serve only corruption prevention goals. For example, administrative simplification requires a total methodological change for the whole operation of public administration. The system's introduction needs a legal approach: certain tools and operation mechanisms become 
obligatory. The framework also reacts to situations deriving from the inefficiency-more truly put, non-success - of the methods described.

Hereinafter, I review the main elements and the implementation experience of the Hungarian integrity management. The traditional law enforcement and criminal law tools, as well as, whistle-blowing mechanisms are entitled to solve these problems.

\section{The Appearance and Headway of Integrity Approach in Hungary}

In Hungary, the State Audit Office had a pioneering role in introducing integrity approach. In 2007 and 2008, the Hungarian Audit Office in cooperation with the Audit Office of the Kingdom of the Netherlands got acquainted with the Dutch practice of integrity based public administration operating according to the requirements of corruption assessment and analysis. The concept, as well as the operating method based on it got into the civil and professional knowledge through the Integrity Project launched by the State Audit Office in 2009.

Since 2012, the results of the Audit Office project also appeared in the governmental decision making. ${ }^{5}$ All this was related to the fact that one of the most important focuses of governmental programs was directed to fight against corruption. Like the practice in Holland where social processes urging actions against corruption directed the attention to the importance of integrity, in Hungary integrity also emerged as a part of the anti-corruption fight. Until then, integrity was regarded the "partner", the addition to the vigorously dominant legal approach. The reason for its progress was that integrity development offered up-to date and progressive possibilities on the basis of international experience.

As for legal actions, the Public Administration Corruption Prevention Program [9] was the first milestone; it defined measures for 2012-2014. This comprehensive, strategic package of measures had a brand new approach: besides criminal law, the decreasing of corruption risks, the strengthening of organisational integrity and measures supporting ethical operation were also emphasised.

The rule of this program that entered into force on $1^{\text {st }}$ February 2013, introduced integrity management for public service bodies.

The elements of the new approach were carried on, at the same time replacing the strategy earlier, by the National Anti-Corruption Program related to 2015-2018. [10] The new program's main step forward: it expands over the public administration system and involves other fields of the state operation (justice, local governments) even the business sector, and takes measures for civil awareness.

Regarding the stages of development, it is important to mention that a governmental official—responsible for the coordination of integrity management—was appointed in 2014. The National Protective Service directed by the Minister of the Interior is in charge for the development and harmonisation of integrity management, analyses and evaluates integrity and corruption risks on governmental level. The Service is basically a crime prevention and detection organisation, its scope of authority includes fight against corruption and other

See Government Decision No. 1104/2012 (IV. 6.) on the adoption of the Anti-Corruption Program of the

Public Administration, Magyary Zoltán Public Administration Development Program (2012). 
interior violations of law by law enforcement tools. Connecting integrity measures and tasks with this organisation opens new perspectives. The settling of the corruption prevention and integrity toolbox into one organisation makes a new, modern kind of experience elaboration possible.

Thus, we could observe the appearance of integrity approach in international trends and its gradual growth between 2009-2013. The period of its stabilisation, awareness-raising and intensification in practice lasts even until today.

Analysing integrity management, we cannot ignore the investigation of its medium; public administration and its organisation. In Hungary, since 2011, the comprehensive transformation of the public administration system have started; ${ }^{6}$ the strategic objective was to create a "Good State". Under the aegis of unification and simplification, the remaking of territorial administration, the reconstruction of county government offices and the termination of several public administration bodies was completed.

The exact definition of the processes and indicators embodied in the daily practice of Good State and Governance inspired scientific workshops, too. ${ }^{7}$ The concept of Good State integrating the practical application of ethical norms in public service and scientific studies is closely linked to the concept of Good Governance and good public administration. [11] The requirement to develop public administration integrity inevitably fits into this frame.

Thus, integrity approach originally came into light related to corruption prevention, however, it is obvious - regardless this fact — the remaking process of the Hungarian public administration could not go without it, either. The new challenges and organisational transformation necessarily led to the integrity approach's headway.

\section{The Elements of the Hungarian Integrity Management}

As for the instruments of the Hungarian integrity management: two main approaches can be seen. The first one-meaning a narrower circle-includes only the tools accepted and named by the government act on integrity management. In a broader interpretation, each legal institution and measure can be included that is designed to ensure a legal, effective and ethical public service. In the first case, the circle of tools is quantifiable and can be identified in the legislative provision. The second one is a lot more complex and the circle of tools needs separate principle basis.

This study presents the second approach and describes the integrity developing tools listed by international trends; those ones consolidated in the Hungarian legislation and their effect on integrity is the objective of investigation and attention.

\footnotetext{
$6 \quad$ See the Magyary Zoltán Public Administration Development Program (2011), Magyary Zoltán Public Administration Development Program (2012), Public Service Development Strategy 2014-2020.

7 The Institute for Research and Development on State and Governance of the National University of Public Service annually publishes the Good State and Governance Report.
} 


\section{Integrity Risk Analysis and Evaluation, the Practice of the Integrity Report}

One of the most important elements of the prevention concept is represented in the ordinance that obligates bodies to the annual survey of integrity and corruption risks. To treat the risks identified by the survey an action plan must be prepared; its fulfilment must be published in a public integrity report. ${ }^{8}$ [12]

The tasks adopted to the body's internal control processes must be performed in the context of the so called integrated risk management system. The internal control system as a process system also helps to achieve goals. The internal control system covers the principles, procedures, regulations which can enable the prevention, exploration and correction of obstructive events and this way supports to meet the target of the organisation. So, in this practice, integrity is one element of control environment; as to risk management- the tool of integrity management-it cannot be effective without the full knowledge of the operation process of the organisation.

In my research of action plans and reports, on the one hand I studied how the bodies satisfied the requirements, on the other hand, I analysed the content of the documents.

According to my findings, the public service bodies have been making action plans and integrity reports with increasing intensity since 2014. In 2014 the number of public administration bodies obliged to perform an integrity report was 101; 40\% (40 pieces) published it. In 2015, the figures were 91 bodies, 62 out of them-68\%-(62 pieces) fulfilled the task. Due to the already mentioned reforms, the number of bodies obliged to give integrity reports significantly decreased; it was 72.57 out of them-79\%—-sent in the integrity account. ${ }^{9}[17]$

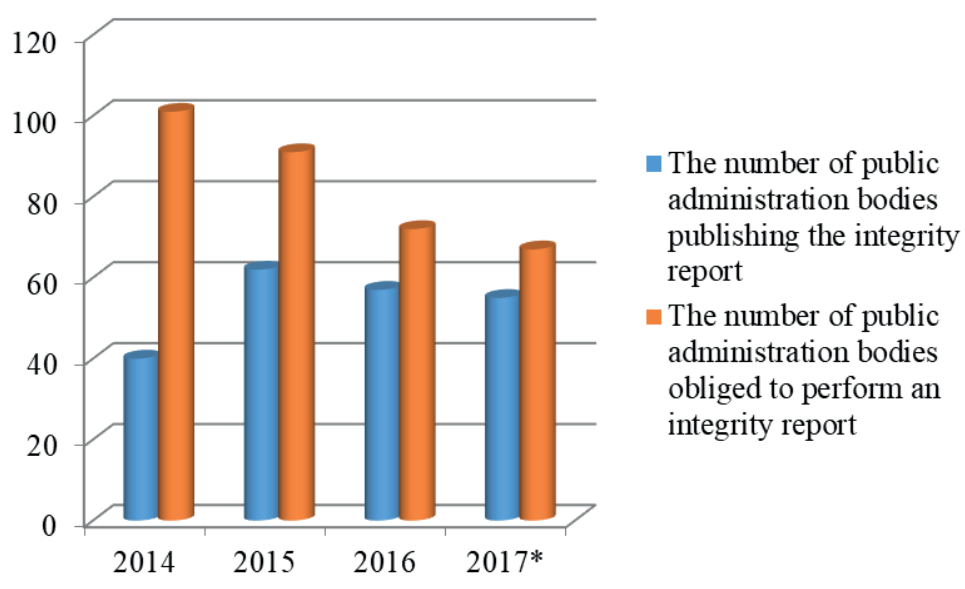

Figure 2. The number of integrity reports. (Edited by the author based on [17].)

\footnotetext{
8 The reports are published on the website http://korrupciomegelozes.kormany.hu. The risk analysis, evaluation and the preparation of the integrity report is helped by a methodological guide.

9 Source: The statistics of the National Protective Service and website.
} 
As for the content analysis ${ }^{10}$ of the measures implied in the reports, I can suggest the following.

It is important to emphasise above all that the survey of risks is the "home affair" of the administration body, as well as, what measures it takes to prevent and manage the risks. On the other hand, the implementation of the measures - the integrity report-must be made public. As the report is prepared with the help of a methodological guide-it must give an itemised list of the measures and show the results in detail, so the measures involved also take air. In addition, the report is expected to justify according to what criteria the measures of the action plan have been chosen.

The public administration integrity report primarily summarises the experience of the implementation of the measures which are considered relevant in order to strengthen integrity, decrease corruption risks, and how the accomplishments can be concluded.

In the study, the measures involved in the reports, on terms of their corruption prevention and integrity effects — can be divided as below:

a) Building up an integrity management organisation

According to the law, an integrity advisor ${ }^{11}$ must be appointed by the head official, however, the legislator does not give any further guideline how and in what frame the legislation provisions are to be implemented.

Analysing the reports from this point of view, the bodies can be divided into two groups. One group — representing the majority_includes bodies in which the appointed advisor, as a general rule does his job, the tasks given by the report on his own, without any institutional support. The other group includes bodies where under the direction of the advisor and with the approval of the head official, a coordination and some kind of organised mechanism come into being in order to attend integrity tasks.

b) Measures supporting integrity on individual level

Here, an extensive investigation of job descriptions and officials' scope of activities related to integrity approach was done, ethical and integrity training were organised by the public administration bodies, they also expressly supported the integration of the new officials getting into the organisation.

c) Procedure of complaints and public interest disclosures

The head of the body is obliged to receive and investigate the complaints related to abuses, deficiencies and corruption risks in the functioning of the body. From an organisational integrity point of view, the exploration of events and situations endangering, offending or threatening the body's operation is of high importance. The measures in the report basically are in connection with the regulation of this procedure. They clearly make efforts for the simplification of the process in order to extensively familiarise the procedure of public interest disclosures.

d) The order of receiving lobbyists

As keeping contact with lobbyists is a tender spot of promoting integrity, that is why to adhere to the law is supported by the methodological guide. [13]

10 The analysis included the reports of 2015 and 2016. Since 2017 the ones completed until the end of February 2017.

11 Persons appointed to act as integrity advisors shall be officers with higher education qualification and at least three years of professional experience in public administration and shall be suitable for and ethically worthy of the position on the basis of their personal ethics and professional skills. 
The bodies are obliged to discover annually the risks of this field and take the necessary measures to fight against them. In most reports, the tasks to be taken are properly defined.

e) Organisation-specific provisions

A significant proportion of the measures is connected to the issues listed above. The basis of action plans is risk surveying. We may presuppose that organisations with the same or similar scope of authority (e.g. government offices for the capital and counties) meet almost the same challenges. However, we cannot ignore situations deriving from territorial location (for example the Capital) or other circumstances (e.g. changing scope of activity of the public administration body or the transformation of an organisational unit) that can influence corruption risks. From the starting point that every organisation is created by people and the tasks delegated by legislation are performed by officials, consequently, the risk exposure of certain bodies cannot be identical even if the scope of the activity is the same. Accordingly, the organisationspecific measures must also be found in the reports. For instance, they appear in the integrity analysis of certain special official activities, or in the training of especially risk exposed employees.

\section{Focus on the Integrity of Public Servants}

Public servants are measured with higher expectations. These expectations are represented both in the employment criteria and the additional requirements for public servant workload. In addition, all these are coupled with normative standards of conduct during worktime and outside office hours.

In this respect, the appreciation of integrity can be traced in the appearance of certain specific legal institutions.

The legal institutions of unworthiness and untrustworthiness/loss of trust were introduced in the civil public service, in 2011. Unworthiness can be set if the official's conduct either at work or outside working hours severely ruins the prestige of his position/post, the credit of the employer or the trust of society in good public administration. The unworthy official's legal relationship to public service must be terminated; doing so, the legislator disciplines the violation of the public service integrity as a whole.

Untrustworthiness means the infringement of professional loyalty. Loyalty, as a commitment to public service principles, can be considered the keystone of integrity.

As for Law Enforcement Corps, impeccable lifestyle is a basic requirement for employment, the legal conditions of its control were set in $1996 .{ }^{12}$ In 2011, however, the integrity test as a new legal institute was first introduced exclusively for law enforcement authorities.

The purpose of the integrity test is to establish whether or not the person concerned complies with the statutory requirements of their job. In order to establish this, the agency carrying out the integrity test shall create artificial situations that happen or may happen in real life in the course of doing the given job.

12 See Act XLIII of 1996. 
Since 2013, the circle of the personnel who can be tested by this integrity test has gradually been expanding. ${ }^{13}$ It is important to note that the expansion has been made related to the public administration activity.

Namely, the law does not specify limited organisational units, but focuses on public service activities outstandingly endangered by integrity and corruption risks. ${ }^{14}$ In this context, the conscious application and implementation of integrity approach in legislation can be found.

The integrity test goes far beyond the repression of possible violations of law; it also serves prevention purposes. Originally, it got into public knowledge through the exploration of a corruption case. However, its main point is not only limited to individual responsibility, it also involved the legality and professionalism, furthermore, the official's conduct while acting.

The increased emphasis on individual integrity can also be traced by ethical responsibility at the civil public service obtaining legal basis in 2012. Defining ethical standards and requirements is one of the keystones of integrity approach: so I am especially dealing with it below.

\section{Strengthening Professional Ethics Awareness Raising}

"Public service depends on public servants"-wrote Zoltán Magyary, Government Commissioner in a proposal to the Prime Minister regarding the economical operation and efficiency of public administration. [14] The key figure of integrity approach is the public servant; the person - who has taken an oath to serve the public good — can get into several situations that causes an ethical dilemma.

The strengthening of professional ethics awareness raising should be put into the complex system of integrity approach.

It may be explained by a number of interrelated factors:

- " "good governance” and “efficient public service” have become public policy priorities;

- the economic crisis has added to the importance of ethical operations;

- pressure to respond to poorer public confidence in public offices and public administration;

- higher expectations from society and citizens towards public service;

- the continuous transformation, reform and reorganisation of the public sector;

- putting the skills of public servants to the test;

- complexity of values, conflicting values and value crisis in all fields of life;

- stronger requirements for openness, transparency and accountability;

- significance of anti-corruption efforts to public policy. [7]

The creation and implementation of professional ethical norms was put into the scope of the public bodies born in 2012: the Hungarian Government and State Officials Corps,

See Act LXXXVIII of 2013.

14 According to Act XXXIV of 1994 on the Police, the state servant who is entitled to make or prepare decisions or perform supervision in the course of a naturalisation, asylum, alien policing, expropriation, construction administration health and safety authority and supervision, property registration authority procedure. 
the Hungarian Law Enforcement Corps. Based on statuary authorisation, the public bodies accepted their ethic codes the next year.

The legislation entitles the Corps to conduct the ethical procedures; the tasks are performed by the boards elected by the members: the civil servant officials and the professional staff of law enforcement corps. The possibility of having a say into the matter of creating ethical rules and the implementation by elected officials ensures a new kind of legitimacy and brings legislation closer to public service employees, thus strengthening dedication to integrity.

The author of this study has been the Vice President of the Hungarian Government and State Officials Corps since 2012, so directly participates in the processes. The public body payed outstanding attention to carrying out its Ethics Code and solving initial difficulties. Professional ethics has occupied a central position in the Corps' operation since then. Beyond conducting procedures, conferences, trainings at public administration bodies organised by the Corps also contribute to the promotion of professional ethics.

The education of integrity advisors at the National University of Public Service was launched in 2012, and extensive integrity and ethics courses started in the retraining system. ${ }^{15}$ [15] Since 2012, the consolidation and maintaining all these have been supported by a valid legal requirement which obligates officials to carry out at least one anti-corruption course during a training cycle.

Professional ethics moving to new foundations strengthens integrity on the individual level; helps uncover and solve conflicts of values, so contributes to the elimination of corruption risks on the individual level.

\section{Summary}

In Hungary, like in many other countries - it was corruption prevention that directed the attention to integrity. An integrated public service and public servant is resistant against corruption and violations of law; however, integrity investigated in a complex way is considered more than a simple corruption prevention tool.

Integrity approach is the peculiarity of the value based public administration. Consequently, the efficiency of the comprehensive organisational transformation of the public administration launched in 2011 fundamentally needs its development. The legal foundations of a modern integrity based culture have already been established in Hungary. Presently, we are in the period of its consolidation. One of the most important basic conditions is the application of integrity culture tools at all public administration levels:

- There are promising results; risk analysis and assessment have become an integral part of the daily operation of public administration.

- The reports on measures designed to present risk prevention and the execution of the actions against them are public, it means an additional responsibility for head officials.

- On individual level, as for commitment to public service work, a new kind of approach has been added by ethical responsibility.

15 The EU Anti-Corruption Report 2014 mentioned the modernity of the trainings. 
- Public servants' awareness raising is supported by trainings, they-beyond knowledge transfer-can also be used to discuss current dilemmas at work.

Concerning the Hungarian integrity management system, two characteristics make it special: the central coordination of integrity management is the task of a law enforcement authority, the National Protective Service. The unification of preventive and law enforcement approaches within one organisation and the utilisation of the accumulated experience open new perspectives.

The Law entitles the occupation policy public bodies to create the professional ethics rules. As the public body organisations work on the border between the civil and state spheres, their involvement strengthens the legitimacy of professional ethics.

The desired goal of integrity development is to ensure the proper and effective functioning of public service enforcing public interest. The focus is on the goal. Accordingly, the experience of the initial years direct attention to the fact that the newly introduced tools of the integrity management cannot achieve results if we do not interpret them together with other long ago mechanisms on the same purpose operating for decades.

\section{References}

[1] JUHÁSZ L. M. - RIGÓ A.: Korrupciómegelőzés és integritás szemlélet a közszolgálatban. [Corruption Prevention and Integrity Management in the Public Service.] Budapest, Nemzeti Közszolgálati Egyetem, 2014.

[2] Survey for the $42^{\text {nd }}$ meeting of the Directors-General of the public service of the European Union Member States. Ethics in the Public Services of the European Union Member States. Collaboration between the Irish and the Dutch presidencies. https://circabc.europa.eu/ webdav/CircaBC/eupan/dgadmintest/Library/6/3/meetings_presidency_2/14-15_stockholm/ documentation/HRWG\%201\%20-\%20Publications\%20on\%20ethics\%20-\%20Hedenskog. doc (Downloaded: 27.06.2019)

[3] Comparative Study on the Public-service Ethics of the EU Member States. European Public Administration Network, 2006. http://workspace.unpan.org/sites/internet/Documents/ UNPAN047469.pdf (Downloaded: 27.06.2019)

[4] Towards a Sound Integrity Framework: Instruments, Processes, Structures and Conditions for Implementation. Paris, Organisation for Economic Co-operation and Development, 2009. www.oecd.org/officialdocuments/publicdisplaydocumentpdf/?doclanguage=en\&cote=GOV/ PGC/GF(2009)1 (Downloaded: 15.02.2018)

[5] SÁNTHA Gy. - KLOTZ P.: Törzsanyag az Integritásmenedzsment címú tantárgyhoz. [Integrity Management.] Budapest, Nemzeti Közszolgálati Egyetem, 2013. http://korrupciomegelozes.kormany.hu/download/7/de/b0000/Klotz\%20 P\%C3\%A9ter_S\%C3\%A1ntha\%20Gy\%C3\%B6rgy_Integrit\%C3\%A1smenedzsment_ tananyag.pdf (Downloaded: 16.02.2018)

[6] BÁGER G.: Korrupció: büntetés, integritás, kompetencia. [Corruption: Punishment, Integrity, Competence.] Budapest, Akadémiai Kiadó, 2012.

[7] PALLAI K. - KIS N.: "Towards Integrity” Integrity Education and Research at the National University of Public Service. Public Finance Quarterly, 592 (2014), 149-163. 
E. DARGAY: The Implementation and Experience of Integrity Management in Public Administration

[8] Quality of Public Administration. A Toolbox for Practitioners. Luxembourg, Publications Office of the European Union, 2015. http://ec.europa.eu/esf/

BlobServlet?docId=13941\&langId=en

DOI: https://doi.org/10.2767/38487

[9] 1104/2012. (IV. 6.) Korm. határozat a korrupció elleni kormányzati intézkedésekrôl és a Közigazgatás Korrupció-megelőzési Programjának elfogadásáról. [Government Decision No. 1104/2012 (IV. 6.) on the adoption of the Anti-Corruption Program of the Public Administration.]

[10] Nemzeti Korrupcióellenes Program (2015-2018). [National Anti-Corruption Program (2015-2018).] http://korrupciomegelozes.kormany.hu/download/9/ff/91000/NKP\%20 Program.pdf (Downloaded: 21.02.2018)

[11] KAISER T. - KIS N. szerk.: A jó állam mérhetősége. [Measuring the Good State and Governance.] Budapest, Nemzeti Közszolgálati Egyetem, 2014. https://akfi.uni-nke.hu/ document/akfi-uni-nke-hu/a-jo-allam-merhetosege-2.original.pdf (Downloaded: 21.02.2018)

[12] Módszertani útmutató a kontrollkörnyezet és az integrált kockázatkezelési rendszer kialakításához. I. rész. [Methodological Guide for the Integrated Risk Management System. Vol. 1.) http://korrupciomegelozes.kormany.hu/download/8/7f/a1000/I\%20rész.pdf (Downloaded: 01.03.2018)

[13] Módszertani útmutató. Az érdekérvényesitőkkel való kapcsolattartás szabályainak alkalmazásához. [Methodological Guide for the Keeping Contact with Lobbyists.] http://korrupciomegelozes.kormany.hu/download/ e/08/71000/M\%C3\%B3dszertani\%20\%C3\%BAtmutat\%C3\%B3\%20az\%20 \%C3\%A9rdek\%C3\%A9rv\%C3\%A9nyes\%C3\%ADt\%C5\%91kkel\%20val\%C3\%B3\%20 kapcsolattart\%C3\%A1s\%20szab\%C3\%A1lyainak\%20alkalmaz\%C3\%A1s\%C3\%A1hoz.pdf (Downloaded: 23.02.2018)

[14] MAGYARY Z.: A magyar közigazgatás gazdaságosságának és eredményességének biztosítása. A m. kir. miniszterelnök úr elé terjesztett javaslat. [The Economy and the Efficiency of the Hungarian Public Administration.] Budapest, Athenaeum, Irodalmi és Nyomdai Rt., 1931.

[15] Az Európai Unió antikorrupciós jelentése. [EU Anti-Corruption Report.] Brüsszel, Európai Bizottság, 2014. http://korrupciomegelozes.kormany.hu/download/4/49/90000/ EU\%20Antikorrupci\%C3\%B3s\%20Jelent\%C3\%A9s\%20-\%20Mell\%C3\%A9klet\%20 Magyarorsz\%C3\%A1gr\%C3\%B3l.pdf (Downloaded: 23.02.2018)

[16] DARGAY E. - JUHÁSZ L. M. szerk.: Antikorrupció és integritás. [Anti-Corruption and Integrity.] Budapest, Nemzeti Közszolgálati Egyetem, 2015.

[17] Korrupciómegelözés. [Prevention of Corruption.] http://korrupciomegelozes.kormany.hu (Downloaded: 23.02.2018) 